\title{
THE EFFECT OF SEASON AND PARITY ON THE REPRODUCTIVE PERFORMANCE OF SOWS
}

\author{
Stanimir Dimitrov ${ }^{1}$, Vesna Karapetkovska-Hristova ${ }^{2}$, Ljupce Kochoski², \\ Biljana Trajkovska², Borche Makarijoski², Vesna Prodanovska-Poposka², \\ Godswill Ntsomboh-Ntsefong ${ }^{3}$
}

${ }^{1}$ Department of Genetics, Breeding and Reproduction, Faculty of Agriculture, Trakia University, Stara Zagora, Bulgaria

${ }^{2}$ Department of Biotechnology, Faculty of Biotechnical Sciences - Bitola, University ,, St. Kliment Ohridski“, Republic of Macedonia

${ }^{3}$ Institute of Agricultural Research for Development (IRAD-CEREPAH), B. P. 243 Douala, Cameroon

Received 2 November 2017; Received in revised form 13 February 2018; Accepted 3 March 2018

\begin{abstract}
The aim of this study was to analyze the effect of season and number of parity on the reproductive performance of sows kept on a commercial farm. To achieve this objective, 800 nrs productive parent sows and a total of 958 parities were analyzed. The results show that sow's breeding season had a significant effect on the weaning-to-oestrus interval, the farrowing rate, the litter size and weaning piglets with positive results during autumn, winter and spring seasons. The number of parity has a significant effect on the weaning-to-oestrus interval, litter size and weaning piglets with acceptable values in sows with more farrowing. The results of this study on a pig farm with analysis which highlights the risk factors associated with reproductive performance of sows, could be used to improve sow farm practices.
\end{abstract}

Key words: crossbreed sows, reproductive parameters, season, parity

\section{INTRODUCTION}

The breeding season and the parity number/ age of animals are two of the main determinants of sow reproductive functions (1). These two factors directly affect animal reproductive performance, hence the analysis of their effect is of a great importance for commercial herd production. The season parameters (temperature, day light duration, etc.) directly influence the main reproductive performance of sows. This is manifested by a

Corresponding author: Ass. Prof. Vesna Karapetkovska Hristova, PhD E-mail address: v.primavera79@gmail.com

Present address: Department of Biotechnology, Faculty of Biotechnical Sciences - Bitola, University „St. Kliment Ohridski“,

Republic of Macedonia

Phone: + 38947238 276; +38971318777

Copyright: (C) 2018 Dimitrov S. This is an open-access article published under the terms of the Creative Commons Attribution License which permits unrestricted use, distribution, and reproduction in any medium, provided the original author and source are credited.

Competing Interests: The authors have declared that no competing interests exist.

Available Online First: 15 July 2018

Published on: 15 October 2018

https://doi.org/10.2478/macvetrev-2018-0019 decline in their reproductive abilities during the warm summer/autumn months $(2,3,4)$. The number of parity/age of the sows, which is associated with the physiological status of the animals (growth, development of the reproductive system, body condition, etc.), is another independent factor determining the reproductive functions of the sows (5), with proven tendencies to increase the reproductive parameters in sows with $\mathrm{III}^{\text {th }}-\mathrm{VI}^{\text {th }}$ parities $(6,7)$.

The aim of this study was to determine the effect of season and parity on the reproductive performance of sows.

\section{MATERIAL AND METHODS}

The research was carried out in a commercial pig farm located in the north region of Bulgaria during the period between January-December 2015. 
Experimental animals, housing, feeding and drinking management

The experimental materials used for this study consisted of 800 nrs. of productive parent sows

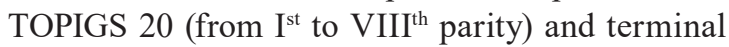
crossbreed boars from line Top Pi.

The boars were kept in individual pens with 7,00 sq. meters/head. The young gilts were housed in group pens (10 nrs.) at 1,00 sq. meters/head. After insemination, sows were housed in gestation crates for a period of one month. The animals with confirmed gestation were kept in buildings with a capacity for $320 \mathrm{nrs}$. of sows at 2,25 sq. meters/ head containing electronic feeding stations (total of $6 \mathrm{nrs}$. feeding stations per building). The farrowing sows were housed in individual farrowing pens. with 26 - 28 days of lactation period.

Sows were fed ad libitum depending on the parity and body condition of the animals (according to the company's recommendations), and had free access to a low-pressure nipple drinker.

\section{Artificial insemination and pregnancy diagnosis}

Semen was collected no more than twice per week from boars housed at the same farm by using the Gloved Hand Technique. The obtained ejaculates were individually assessed for volume, number of sperm cells, and percent of motile spermatozoa. Volume (without gel fraction) was determined by using a graduated glass vessel with precision of 0.01 $\mathrm{ml}$. The number of sperm cells was determined by using a photometer (Metro sperm-MAGAPOR, Spain). Percentage of motile spermatozoa (0 to $100 \%$ ) was subjectively evaluated with a light microscope at a magnification of $100 \mathrm{X}$. The minimum standards for an ejaculate to be acceptable for use were the following: volume - >80 ml; color - milky; odor normal; number of sperm per ml - $100 \times 10^{6}$; motility - $>70 \%$ and agglutination - $<30 \%$. The semen was diluted in SOLUSEM ${ }^{\circledR}$ extender (AIM world wide,
Holland) at a rate of $1+3-1+10$ and packaged in $80-100 \mathrm{ml}$ plastic bottles containing $3.0 \times 10^{9}$ live spermatozoa. Diluted sperm was stored in a cooler unit at $15-17^{\circ} \mathrm{C}$ until used within 24 to 48 hours after collection. Oestrus detection of gilts and weaned sows was performed twice per day (09:30 to 10:30 and 15:00 to 16:00) with a mature boar. All animals were inseminated twice per oestrus with a spiral type catheter using the Hands-free Cervical Technique. The pregnancy was diagnosed between 23 - 25 days after insemination with an ultrasound detector Smart Scan (HRE Agrar Elektronik GmbH, Germany).

\section{Reproductive performance and statistical analysis}

The estimation of reproductive performance was conducted for each animal included in this study. In fact, the following reproductive parameters were analyzed: 1) weaning-to-oestrus interval (days) including saws showing signs of heat 3-12 days after weaning; 2) farrowing rate $(\%) ; 3$ ) gestation length (days) - calculated from the first day of insemination to the day of farrowing; 4) litter size - total born piglets and live born piglets;- saws were included that gave birth to a minimum of 4 pigs and 5) number of weaning piglets. Before the analysis of data, the animals were categorized into: 1) season of insemination: Spring (MarchApril-May), Summer (June-July-August), Autumn (September-October-November) and Winter (December-January-February); 2) parity of sows: I, II, III, IV, V, VI and VII-VIII. For the purposes of this research a one-way ANOVA was used for the statistical analysis. The post hoc comparisons were done by a LSD test. All calculations and statistical analyses were processed by a statistical package Statistic for Windows Software (Stat Soft Inc., 1994), and for nonparametric analysis of means and proportion the Student's t-criterion was used. The data were collected by F-Central FarmManager software programme (Fancom BV, Nederland).

Table 1. Effect of the season on the reproductive performance of sows (mean $\pm \mathrm{SD}$ )

\begin{tabular}{lllll}
\hline Reproductive parameters/season & Spring & Summer & Autumn & Winter \\
\hline Number of animals & 278 & 252 & 319 & 241 \\
Weaning-to-oestrus interval, days & $5.36 \pm 1.11^{\mathrm{A}}$ & $5.46 \pm 1.56^{\mathrm{B}}$ & $5.13 \pm 1.14^{\mathrm{AB}}$ & $5,33 \pm 1,35$ \\
Farrowing rate, $\%$ & 85,61 & 84,92 & 92,47 & 87,55 \\
Gestation length, days & $114,41 \pm 0,66$ & $114,18 \pm 1,08^{\mathrm{AB}}$ & $114,50 \pm 1,27^{\mathrm{A}}$ & $114,55 \pm 0,86^{\mathrm{B}}$ \\
Total born piglets/litter, nrs & $13.09 \pm 2.85^{\mathrm{A}}$ & $13.67 \pm 3.16^{\mathrm{B}}$ & $14.43 \pm 3.48^{\mathrm{ABC}}$ & $13.40 \pm 3.42^{\mathrm{C}}$ \\
Live born piglets/litter, nrs & $12.54 \pm 2.96^{\mathrm{A}}$ & $12.65 \pm 2.95^{\mathrm{B}}$ & $13.33 \pm 3.19^{\mathrm{ABC}}$ & $12.38 \pm 3.43^{\mathrm{C}}$ \\
Weaning piglets/litter, nrs & $11.90 \pm 0.68^{\mathrm{A}}$ & $11.63 \pm 1.36^{\mathrm{AB}}$ & $12.04 \pm 1.09^{\mathrm{BC}}$ & $11.81 \pm 1.09^{\mathrm{C}}$ \\
\hline
\end{tabular}

${ }^{A B C}$ values in the same rows with different superscript are significantly different between groups $(p<0.05)$ 
Table 2. Effect of parity on the reproductive performance of sows (mean \pm SD)

\begin{tabular}{cccccccc}
\hline $\begin{array}{c}\text { Reproductive } \\
\text { parameters/parity }\end{array}$ & I & II & III & IV & V & VI & VII-VIII \\
\hline $\begin{array}{c}\text { Number of animals } \\
\begin{array}{c}\text { Weaning-to- } \\
\text { oestrus interval, } \\
\text { days }\end{array}\end{array}$ & 522 & 224 & 152 & 137 & 101 & 86 & 55 \\
$\begin{array}{c}\text { Farrowing rate, \% } \\
\begin{array}{c}\text { Gestation length, } \\
\text { days }\end{array}\end{array}$ & $114.23 \pm 1.04^{\mathrm{AB}}$ & $114.26 \pm 0.78^{\mathrm{CD}}$ & $114.60 \pm 0.52^{\mathrm{AC}}$ & $114.50 \pm 0.80$ & $114.82 \pm 0.81^{\mathrm{BD}}$ & $114.46 \pm 0.91$ & $114.60 \pm 0.72$ \\
$\begin{array}{c}\text { Total born piglets/ } \\
\text { litter, nrs }\end{array}$ & $13.00 \pm 3.11^{\mathrm{ABCDE}}$ & $14.12 \pm 3.17^{\mathrm{AF}}$ & $14.25 \pm 3.07^{\mathrm{BG}}$ & $14.29 \pm 3.56^{\mathrm{CH}}$ & $13.79 \pm 3.22^{\mathrm{D}}$ & $13.48 \pm 3.28$ & $12.95 \pm 3.82^{\mathrm{EFGH}}$ \\
$\begin{array}{c}\text { Live born piglets/ } \\
\text { litter, nrs }\end{array}$ & $12.38 \pm 3.14^{\mathrm{ABCD}}$ & $13.36 \pm 3.05^{\mathrm{AEF}}$ & $13.44 \pm 3.06^{\mathrm{BGH}}$ & $13.11 \pm 3.29^{\mathrm{CIJ}}$ & $12.66 \pm 3.14^{\mathrm{K}}$ & $11.98 \pm 2.97^{\mathrm{EGA}}$ & $11.07 \pm 2.89^{\mathrm{DFHJK}}$ \\
$\begin{array}{c}\text { Weaning piglets/ } \\
\text { litter, nrs }\end{array}$ & $11.94 \pm 1.29^{\mathrm{ABC}}$ & $12.06 \pm 1.10^{\mathrm{DEF}}$ & $12.00 \pm 0.82^{\mathrm{GHI}}$ & $11.87 \pm 0.86^{\mathrm{JK}}$ & $11.66 \pm 0.91^{\mathrm{ADGL}}$ & $11.47 \pm 0.94^{\mathrm{BEHJ}}$ & $11.13 \pm 0.83^{\mathrm{CFIKL}}$ \\
\hline
\end{tabular}

ABCDEFGHIJKL values in the same rows with different superscript are significantly different between groups $(\mathrm{p}<0.05)$

\section{RESULTS}

A total of 958 litters were analyzed. The statistical analysis confirmed the significant effects of the two studied factors (season and parity) for evaluating reproductive parameters of sows. The reproductive parameters of the analyzed sows depending on season are presented in Table 1.

The largest value of weaning-to-oestrus interval occurred during the summer and the lowest interval during autumn, winter and spring $(p<0.05)$. The same tendencies were found in the farrowing rate (statistically unconfirmed differences) and in the length of the gestation period $(p<0.05)$ of the animals. Prolificacy (number of total born and live born piglets in litter) appeared highest in animals bred during the autumn months and the lowest in those inseminated in winter and spring $(\mathrm{p}<0.05)$. Logically, the number of weaning piglets has the highest values in animals bred in autumn and the lowest values were from the animals inseminated during the warm summer months.

The reproductive parameters of the experimental sows regarding the influence of number of parity/ age of animals are presented in Table 2.

As for the weaning-to-conception interval, a statistically proven tendency to extend its duration in the animals of $\mathrm{I}^{\text {st }}$-II ${ }^{\text {nd }}$ farrowing compared to sows with more parities $(\mathrm{p}<0.05)$ was established. For the percentage of farrowing sows, a statistically unconfirmed tendency to increase the values of sows with more farrowing ( $\mathrm{III}^{\mathrm{rd}}, \mathrm{IV}^{\text {th }}$ and $\mathrm{V}^{\text {th }}$ ) was found in comparison with animals with It_ $^{\text {st }}$ II $^{\text {nd }}$ parities, whereas lowest values are shown for the animals on $\mathrm{VII}^{\text {th }}-\mathrm{VIII}^{\text {th }}$ parity. The duration of pregnancy follows a statistical dependence on the increase in sows with more farrowing $(p<0.05)$. The shortest duration of the pregnancy was from the young sows ( $\mathrm{I}^{\text {st }}$ farrowing), and the longest duration was recorded from the animals of the $\mathrm{III}^{\mathrm{ty}}$, VII ${ }^{\text {th }}$ and $\mathrm{VIII}^{\text {th }}$ parities. An analogous tendency to increase the values of the reproductive parameters with an increase of the number of parity/age of animals was established in terms of the litter size and the number of weaning piglets per litter. The highest values were given for sows with $\mathrm{II}^{\text {nd }}$, $\mathrm{III}^{\text {th }}$ and $\mathrm{IV}^{\text {th }}$ farrowing respectively, and the lowest values were found in the young animals ( $\mathrm{I}^{\mathrm{st}}$ parity) and in those of $\mathrm{VII}^{\text {th }}-\mathrm{VIII}^{\text {th }}$ farrowing.

\section{DISCUSSION}

Reproductive parameters in sows depend on a complex of endogenous and exogenous factors. In the present study, the season's effect on the duration of the weaning-to-conception interval, the percentage of farrowing sows and the duration of pregnancy and the prolificacy of the animals was established. There is an extended weaning-to-first oestrus of sows during the warm summer months (June-JulyAugust). This extended period is associated with a decrease of the main reproductive parameters in animals, which directly affects the lower percentage of farrowing sows and the number of weaning piglets per litter $(8,9,10,11,12)$. The recovery of ovarian activity after the lactating period during the warm months is under the influence of extended daylight and increased ambient temperature (13). This in turn leads to suppression of the normal secretion 
of gonadotropin-releasing hormones from the hypothalamus (the synthesis of follicle stimulating hormone and luteinizing hormone from the pituitary glands) resulting in prolongation of post-lactation ovulation and suppression of the manifestation of oestral signs (14). The effect of increased ambient temperature would have an indirect influence over the extension of the weaning-to-first oestrus period. It is known that animal appetite is significantly reduced during warm summer months (15), and this energy deficiency in the body suppresses the secretion of luteinizing hormone (14). As a result, formation and ovulation of the follicles after weaning is prolonged, as well as an extension of the weaning period of oestrus (16). On the other hand, a long daylight in summer has a direct effect on decreased melatonin secretion and the secretion of gonadotropin-releasing hormones (17).

The percentage of farrowing sows is lower in the animals bred during the summer months, compared to those in the autumn (the difference is statistically unconfirmed). The main reason for the low value of this indicator is the problem with fertilization, which is reflected in the increased percentage of repeat sows during the summer months. The increased ambient temperature during this "warm" season of the year suppresses the secretion of prolactin from the pituitary gland, which in turn influences the activity of the corpus luteum graviditatis (or suppresses the secretion of progesterone) especially after the $16^{\text {th }}$ day of fertilization (17).

The prolificacy in sows (total number of born and live piglets) depends on complex genetic and paragenetic factors, as the season indirectly affects the size of the litters. In the present study, a decrease in litter size values was observed in the winter and spring months.

The main technological indicator featuring the economic efficiency of sow production is the number of weaned piglets from an animal. In this study, the authors found statistically significant higher values $(\mathrm{p}<0.05)$ of this index in sows delivered in autumn, winter and spring, respectively, which is associated with a significant increase in mortality of suckling piglets while the lactation period during the warmer months of the year.

The analysis of the influence of seasonal factors on the reproductive performance of the animals surveyed in the particular farm/genetics, shows a strong "summer/seasonal infertility syndrome" in sows $(16,18)$. This phenomenon is a result of the combination of two negative factors - the high temperature and the prolonged daylight during the summer's months of the year. The combination of these two factors affects through the neuroendocrine mechanism over the central nervous systemhypothalamus-pituitary-ovarian system (17).

The age of the sows (particularly the number of parity) is another important external factor that affects the reproductive performance of the animals. The results obtained showed a tendency to prolong the duration of the weaning-to-conception interval in the animals on $I^{\text {st }}$ parity. The same trend was also found by other authors $(19,20)$. The probable reason for this is that sows with $\mathrm{I}^{\text {st }}-\mathrm{II}^{\text {nd }}$ farrowing have relatively higher nutritional requirements for their growth (since they have not yet reached the optimum body weight), and, on the other hand, have limited body reserves of protein and fat. These increased nutrition requirements associated with the intake of food during the lactation period and reduced appetite for the animals result in a negative energy balance in the body with the predominance of catabolic processes. All of these factors lead to inhibition of luteinizing hormone secretion, suppression of follicular maturation, resulting in prolongation of the weaning-to-conception period compared to animals on $\mathrm{III}^{\mathrm{rd}}$, $\mathrm{IV}^{\text {th }}$ and $\mathrm{V}^{\text {th }}$ farrowing.

Even though the same dependence is statistically unconfirmed, yet it has been established for a certain percentage of farrowing sows. The lowest values of this reproductive parameter were recorded in the animals of the $\mathrm{I}^{\text {st }}-\mathrm{II}^{\text {nd }}$ farrowing, increasing at the $\mathrm{V}^{\text {th }}$ parity and then again decreasing in their values (VII $^{\text {ty }}-$ VIII $^{\text {ty }}$ farrowing). Similar trends for a 3-5\% lower percentage of farrowing sows were found by other authors $(21,22)$. On the other hand, some workers $(21,23)$ indicate that the highest farrowing rate reaches the $\mathrm{V}^{\text {th }}$ parity, and the authors consider that this age is optimal for culling of the animals. The analysis of the results showed that the saws of the III' ${ }^{\text {ty }}$ IV ${ }^{\text {ty }}$ and $\mathrm{V}^{\text {ty }}$ farrowing had the shortest weaning-to-first oestrus period and had the highest percentage of farrowing animals, respectively.

The lowest amount of total born/live born piglets was observed in the animals of the first farrowing $(\mathrm{p}<0.05)$, whereas this dependence is being associated with the so-called second litter drop syndrome. A number of authors $(24,25)$ point out that this phenomenon is also due to physical immaturity of sows at first farrowing and their increased nutrition requirements, resulting in suboptimal litter size or farrowing rate. Data analysis revealed an increase in the values of the characteristics of the $\mathrm{IV}^{\text {th }}$ and $\mathrm{V}^{\text {th }}$ farrowing, followed by a decrease in $\mathrm{VII}^{\text {th }}$ and VIII ${ }^{\text {th }}$ parity. Similar dependencies for increasing of the litter size at the $\mathrm{V}^{\text {th }}$ birth was determined by other authors $(3,6,7)$. 


\section{CONCLUSION}

In the present study, no dependence was established between litter size of sows and the duration of pregnancy. However there was a statistically significant tendency for prolonged pregnancy in animals with a higher number of total born/live born piglets per litter. The results of the present study are significant from the practical points of view. Season of breeding of sows have significant effect of weaning-to-oestrus interval, farrowing rate, litter size and number of weaning piglets all resulting positively during Autumn, Winter and Spring. The effect of parity on the studied reproductive parameters is considerable in animals of III ${ }^{\text {ty }}$, IV ${ }^{\text {ty }}$ and $V^{\text {ty }}$ parity.

\section{CONFLICT OF INTEREST STATEMENT}

The authors declared that they have no potential conflict of interest with respect to the authorship and/or publication of this article.

\section{ACKNOWLEDGMENT}

The study was supported by the project $9 Ж / 2013$, Agricultural faculty, Trakia University, R. Bulgaria. The authors would like to express their gratitude to prof. Donald G. Levis at the University of Nebraska-Lincoln for his critical review of this manuscript.

\section{REFERENCES}

1. Bloemhof, S., van der Waaij, E.H., Merks, J.W., Knol, E.F. (2008). Sow line differences in heat stress tolerance expressed in reproductive performance traits. J Anim Sci. 86 (12): 3330-3337.

https://doi.org/10.2527/jas.2008-0862 PMid:18708608

2. Love, R.J., Evans, G., Klupiec, C. (1993). Seasonal effects on fertility in gilts and sows. J. Reprod. Fertil. 48 (Suppl.), 191-206.

3. Schwarz, T., Nowicki, J., Tuz, R. (2009). Reproductive performance of polish large white sows in intensive production - effect of parity and season. Ann. Anim. Sci. 9(3): 269- 277.

4. Knecht, D., Srodon, S., Duzinski, K. (2005). The impact of season, parity and breed on selected reproductive performance parameters of sows. Arch. Anim. Breed. 58, 49-56. https://doi.org/10.5194/aab-58-49-2015
5. Schwarz, T., Kopyra, M. (2006). Influence of age on insemination process, and reproductive performance in sows. Animal Science Papers and Reports 24 (suppl. 3): 229-239.

6. Tantasuparuk, W., Lundeheim, N., Dalin, A.M., Kunavongkrit, A., Einarsson, S. (2000). Reproductive performance of purebred Landrase and Yorkshire sows in Thailand with special reference to seasonal influence and parity number. Theriogenology 54, 481-496. https://doi.org/10.1016/S0093-691X(00)00364-2

7. Tummaruk, P., Lundeheim, N., Einarsson, S., Dalin, A. M. (2000). Reproductive performance of purebred Swedish Landrace and Swedish Yorkshire sows: I. Seasonal variation and parity influence. Acta Agriculturae Scandinavica Section A - Animal Science, 50, 205-216. https://doi.org/10.1080/090647000750014331

8. Kemp, B., Soede, N.M. (1996). Relationship of weaning-to-estrus interval to timing ofovulation and fertilization in sows. Journal of Animal Science 74, 944-949.

https://doi.org/10.2527/1996.745944x

PMid:8726724

9. Stancic, B. (1997a). Interval zalučenje-estrus u krmača. 1. Faktori koji određuju trajanje ovog intervala (pregled). [Interval weaning-oestrus in sows.2. Influence of the duriation of this interval to the farrowing rate and size of litters]. Vet. glasnik, 51(3-4): 109-118. [in Serbian]

10. Stancic, B. (1997b). Interval zalučenje-estrus u krmača. 2. Uticaj trajanja ovog intervala na vrednost prašenja i veličinu legla (pregled). [Interval weaning-oestrus in sows.1. Factors determining the duration of this interval]. Vet. glasnik, 51(3-4): 119126. [in Serbian]

11. Borchardt Netto, G. (1998). Causes of variation of oestrus lenght and onset of oestrus-ovulation interval and their relationship with pregnancy rate and litter size in multiparous sows. (Dissertation), Institute for Reproduction, Hanover.

12. Timotijevic, M., Stancic, B., Garcin, M. (2003). Postlaktacijsko estrusno reagovanjei fertilitet krmača (monografija). [Postlactation estoerus reaction and fertiliy of sows]. Poljoprivredni fakultet, Novi Sad. [in Serbian]

13. Peltoniemi, O.A.T., Love, R.J., Heinonen, M., Tuovinen, V., Saloniemi, H. (1999). Seasonal and management effects on fertility of the sow: a descriptive study. Animal Reproduction Science 55, 47-61.

https://doi.org/10.1016/S0378-4320(98)00159-6 
14. Prunier, A., Quesnel, H., Messias De Braganca, M., Kermabon, A. Y. (1996). Environmental and seasonal influences on the return-to-oestrus after weaning in primiparous sows: a review. Livestock Production Science 45, 103-110. https://doi.org/10.1016/0301-6226(96)00007-3

15. Aherne, F.X., Kirkwood, R.N. (1985). Nutrition and sow prolificacy. Journal of Reproduction and Fertility 33 (Suppl.), 169-183.

16. Kirkwood, N.R. (2009). Managing seasonal infertility in sows. Vets.Web. 11, 1-12.

17. Tast, A. (2002). Endocrinological basis of seasonal infertility in sows. (Dissertation) University of Helsinki, Helsinki.

18. Stancic, B., Bozic, A., Stancic, I., Radovic, I., Dragin, S. (2011). Sow seasonal infertility. Contemporary Agriculture 60 (1-2): 195-203.

19. Cavalcante Neto, A., Lui, J.F., Sarmento, J.L.R., Ribeiro, M.N., Monteiro, J.M.C., Tonhati H. (2008). Fatores ambientais e estimativa de herdabilidade para o intervalo desmamecio de fêmeas suínas. [Environmental factors and heritability estimate for the weaning-estrus interval in sows]. Revista Brasileira de Zootecni 37(11): 1953-1958. [in Spanish] https://doi.org/10.1590/S1516-35982008001100008

20. Leite, C.D.S., Lui, J.F., Albuquerque, L.G., Alves, D.N.M. (2011). Environmental and genetic factors affecting the weaning-estrus interval in sows. Genet. Mol. Res. 10 (4): 2692-2701.

https://doi.org/10.4238/2011.November.4.2 PMid:22095595
21. Hurtgen, J. P., Leman, A. D. (1980). Seasonal influence on the fertility of sows and gilts. Journal of the American Veterinary Medical Association 177 (7): 631-635. PMid:7440358

22. Clark, L.K., Schinckel A.P., Singleton W.L., Einstein M.E., Teclaw R.F. (1989). Use of farrowing rate as a measure of fertility of boars. JAVMA 194, 239-243. PMid:2917890

23. Scholman, G.J., Dijkhuizen, A.A. (1989). Determination and analysis of the economic optimum culling strategy in swine breeding herds in Western Europe and the USA. Journal of Agricultural Science 37, 71 - 74.

24. Clark, L. K., Leman A.D. (1986). Factors that influence litter size in sows. Sow News and Information 7, 303-310.

25. Soede, N.M., Hoving, L. L., Leeuwen, J.J.J., Van Kemp, B. (2013). The second litter syndrome in sows; causes, consequences and possibilities of prevention. Proceedings of the 9thInternational Conference in Sow Reproduction, Satellite Symposium, 9-12 June, Olsztyn, Poland, 28-34. 